\title{
Factors That Enhance Or Reduce Productivity Among Cassava Women Farmers In Benue State, Nigeria.
}

\author{
${ }^{1}$ Atagher Monica M., ${ }^{2}$ Okorji, E. C. \\ 1Department of Agricultural Business Management, Akperan Orshi College of Agriculture, Yandev Gboko \\ ${ }^{2}$ Benue State, Nigeria. Department of Agricultural Economics, University of Nigeria, Nsukka Enugu State, \\ Nigeria.
}

\begin{abstract}
This study assessed the factors that influence productivity among cassava women farmers in Benue State, Nigeria. For the study, 87 cassava producing women farmers were selected across Benue State Agricultural producing zones and interviewed. Data analysis was through descriptive statistics and the ordinary least square techniques. The study findings revealed that farming experience, years of education, the use of improved cassava stem cuttings and access to credit significantly influenced the productivity levels of cassava women farmers in the study area. . Respondents identified poor pricing of output, lack of credit, poor soils, processing problems, lack of good market infrastructure, labour supply problems, and high transport costs as factors militating against successful cassava production in the study area. Therefore, to increase crop yields on cassava farms, the study recommends the enhancement of farmers' access to education, improved cassava varieties, education on the proper use of credit and the need for smaller family sizes.
\end{abstract}

Key words: Productivity, Cassava women farmers, Benue State, Nigeria.

\section{Introduction}

Nigerian women's contribution to agricultural production in the country is substantial. Several studies have established this (Arene and Omoregie, 1991; Ijere, 1991; Ogbimi and Williams, 2001; Okoli and Umebali, 2008). Nigerian women make up to $60-80 \%$ of agricultural labour force producing two-third of food crops and $80 \%$ of the food. Afolabi (2008) observed that as much as $73 \%$ of Nigerian women are involved in cash crops, arable crops and vegetable gardening, $16 \%$ in post-harvest activities, $15 \%$ in agro-forestry, while in some states, rural women have virtually taken over the production and processing of arable crops.

In spite of women's numerous contributions to agriculture in Nigeria, the widespread assumption that men and not women make key farm management decisions has prevailed. So when resources are released for agricultural development, women are often marginalized or even excluded (Ijere, 1991; IFAD, 2001). Thus there is a marked disparity between men and women in empowering social amenities like education, improved technology and extension services which has constrained optimization of agricultural production. Therefore, majority of the women farmers have remained poor, grossly overburdened, under empowered and underutilized (Okoli and Umebali, 2008). According to the International Monetary Fund (2004), women in Nigeria are likely to be poorer than men and have fewer options for escaping poverty.

According to Ogbimi and Williams (2001), the reason for women's limited access to income and economic opportunities is that women work at the margin of development efforts and programmes. Other reasons for the neglect of women's contribution to agricultural development and their consequent poverty (especially in Nigeria) include the small and fragmented nature of their farms, their lack of education, information and technical skills, their numerous domestic chores, lack of interest among planners on the role of women, societal attitude and traditions in the African society among others. As a result, $70 \%$ of the world's poorest people (including Nigeria) are women (IFAD, 1992; United Nation Development Programme, 2004, Nsikakabasi and Ukoha, 2010).

Poverty in Nigeria has many dimensions and manifestations including joblessness, over-indebtedness, economic dependence, lack of freedom, inability to provide the basic needs or own assets. Poor people in Nigeria tend to live in dirty localities that put significant pressure on the physical environment contributing to environmental degradation. The poor especially farmers, perceive their economic circumstances to be fraught with uncertainty affected by events over which they have no control, such as primary commodity prices, the volume of rainfall, pest attacks, fire out breaks, changes in soil condition, and social conflicts. Of all these, lack of food is the most critical dimension of poverty (CBN, 2005). Okoli and Umebali (2008) observed that for these rural farmers (including women) to improve their well-being and meet their food requirements, their poverty must be curbed. 
According to Nsikakabasi and Okoha (2010), profiling poverty, identifying and understanding the factors underlying the persistent deprivation of the poor and hungry are imperative for designing suitable policies to meet their needs and improve their well-being. Joochim et al (2004) observed that there is a strong relationship between agricultural productivity, hunger and poverty. In addition, they noted that rates of poverty reduction have been very closely related to agricultural performance particularly the rate of growth of productivity. They further noted that countries that have increased their agricultural productivity the most have also achieved the greatest reductions in poverty. In Nigeria, studies have established that one of the major causes of poverty is the decline in agricultural productivity (Eboh et al, 2006; Ayoola, 2009). This implies that productivity improvements in agriculture could provide one of the routes out of poverty for Nigeria. For this reason, it is imperative to identify the determinants of agricultural productivity in Nigeria. Consequently, this study was undertaken to identify the determinants of productivity among cassava women farmers in Benue state, Nigeria. The cassava crop was selected because studies have shown that cassava transformation is the greatest poverty fighter among crops in Nigeria (Nweke,2004; Fakayode et al, 2008) The study is expected to contribute towards reducing poverty among one of the most vulnerable groups in Nigeria, the women farmers.

\section{Materials And Methods}

Study area, sampling and data collection. This study was conducted in Benue, Nigeria. The state with a population of 4,219,244 people (NPC, 2006) and a total land mass of $34,095 \mathrm{Km}^{2}$ is located between longitude $8^{0} \mathrm{E}$ and $10^{0} \mathrm{E}$, latitude $6^{0} 3^{0} \mathrm{~N}$ and $8^{1 / 2}{ }^{0} \mathrm{~N}$. The state is in North central Nigeria and shares boundaries with Cross River, to the south, Enugu to the south West, Ebonyi to the south, Kogi to the west, Taraba and Nasarawa State to the East and North respectively. It shares an international boundary with the republic of Cameroon to the South East). Benue state is divided into 23 Local Government Areas and has three Agricultural Development Project zones. Benue State has abundant human and material resources. The state is in the rich agriculture land of the Guinea Savannah zone of the Nigeria. The state has two major rivers - the Benue and Katsina- Ala Rivers and several lakes, ponds and streams which are suitable for both upland and fadama crop production. The state has two main seasons, the rainy season which usually starts from April and ends in October with an average precipitation of $1500 \mathrm{~mm}$. The daily mean temperature during rainy season is $28^{\circ} \mathrm{C}$. The dry season is from November to March (BNARDA, 1998).

Multi stage sampling technique was adopted for the study. Stage one was the purposive selection of two cassava producing local governments from each of the three zones in the state, making a total of six Local Governments, stage two was the random selection of two blocks from each of the selected local government areas, making a total twelve blocks. Stage three was random selection of twenty-nine cassava women farmers from the two Local Governments in each zone giving a total of 87 respondents. Information on respondents' socioeconomic characteristics such as age, level of education, marital status, household size others were obtained and analysed.

Analytical Technique: Descriptive statistics such as means, frequencies, and percentages were used to analyse the data. The ordinary least square multiple regression model was used to estimate the determinants of respondents' output. This was similar to the procedure adopted by Alabi and Adebayo (2008). The explicit form of the model was:

$Y_{c}=b_{0}+b_{1} X_{1}+b_{2} X_{2}+b_{3} X_{3}+b_{4} X_{4}+b_{5} X_{5}+b_{6} X_{6}+b_{7} X_{7}+b_{8} X_{8}+b_{9} X_{9}+b_{10} X_{10}$

Where: $Y_{c}=$ output of cassava in $\mathrm{kg}, \mathrm{X}_{1}=$ farming experience of farmers (years),

$\mathrm{X}_{2}=$ years of education (years), $\mathrm{X}_{3}=$ family size of farmer (number)

$\mathrm{X}_{4}=$ amount of fertilizer used $(\mathrm{kg}), \mathrm{X}_{5}=$ use of improved cassava cuttings (dummy, $1=\quad$ improved, 0 otherwise). $X_{6}=$ amount of agrochemicals used (L), $X_{7}=$ farm size in (hectares), $X_{8}=$ total amount of labour used (man-days). $\mathrm{X}_{9}=$ credit use (dummy, $1=$ credit use and 0 otherwise). $\mathrm{X}_{10}=$ access to extension advice (dummy, access $=1,0$ otherwise), $b_{0}=$ intercept, $b_{i=}$ coefficients of the variables used in the regression, $e=$ error term.

\section{Results And Discussion}

\section{Socio- economic characteristics of respondents:}

Table 1 shows that majority of the cassava women farmers $(89.6 \%)$ were between the age range of 20 and less than 60 years. This is because women below the ages of 20 are mostly in school and may not have the time to be involved in cassava production while those above 60 years may be getting too advanced in age for cassava production. This is because cassava production is a vigorous activity that requires adequate attention and responsibility. Those above 60 years were few because they may lack adequate strength and vigor required for managing cassava farms.

About $70.1 \%$ of the respondents had been married. This suggests that they may be high demand for food and additional income as their family sizes increase. Some of the respondents were divorced (13.8\%), while others were divorced (12.7). Only a few (3.3\%) were single. This shows clearly that cassava production in 
the study area is controlled by women with responsibility. About $63.2 \%$ were educated while $36.8 \%$ had no formal education. Among the educated, $33.3 \%$ had primary education, $17.2 \%$ had secondary education while $12.7 \%$ had tertiary education. This shows that cassava production among respondents was dominated by educated women. This is because cassava production requires a lot of technical knowledge and a high level of education is required to understand complex innovations and apply them correctly. Therefore, the more educated the farmer, the more the probability of success in cassava farming.

Majority of respondents (74.7\%) had family sizes of less than 10 persons, $23.0 \%$ had family sizes between 11 20 persons, while $2.3 \%$ had family sizes above 20 . This implies that respondents were women with family responsibility and large family sizes which could provide labour on the farm.

Table 1: Socio-economic Characteristics of Respondents

Variable
Age (years)
$<20$
$20-29$
$30-39$
$40-49$
$50-59$
$\leq 60$
Total
Marital status
Married
Divorced
Widowed
Single
Total
Years of education
No formal education
Primary education
Secondary education
Tertiary education
Total
Family size
$\leq 10$
$11-20$
$>20$
Total

$\begin{array}{rl}\text { Frequency } & \text { Percentage } \\ 3 & 3.4 \\ 14 & 16.1 \\ 23 & 26.4 \\ 21 & 24.1 \\ 20 & 23.0 \\ 6 & 6.9 \\ 87 & 100.0 \\ & \\ 61 & 70.2 \mathrm{~s} \\ 12 & 13.8 \\ 11 & 12.7 \\ 3 & 3.3 \\ 87 & 100.0 \\ 32 & \\ 29 & 36.8 \\ 15 & 33.3 \\ 11 & 17.2 \\ 87 & 12.7 \\ 65 & 100.0 \\ 20 & 74.7 \\ 2 & 23.0 \\ 87 & 2.3 \\ & 100.0 \\ & \end{array}$

Membership of farmers' Associations

Have never been a member

Was once a member

Farming experience (years)

Majority of the respondents (82.8\%) did not belong to any farmers' association. About $5.7 \%$ were once members, while only $11.5 \%$ were currently members. This results imply that majority of respondents were not suitably positioned to receive assistance for farming. This is because most assistance (government, nongovernmental) is usually channeled through organized groups such as farmers' associations. Further enquiries on why they did not belong to any farmers' association revealed that majority of the women farmers lacked knowledge on the benefits of belonging to such associations. Results showed that $58.6 \%$ and $77.0 \%$ had been farming for about 10years and 20 years respectively. This implies that most of the respondents have acquired the needed experience for successful farming.

Determinants of respondent output: The double- log model was chosen as the lead equation for modeling respondent's output. The value of $\mathrm{R}^{2}$ was 0.930 showing that $93.0 \%$ of the variation in the output was explained by the explanatory variables included in the model. The F-ratio (5.352) was significant at $10 \%$ level showing that the combined influence of the explanatory variables was strong. The regression coefficients indicate the partial productivities of the various inputs used. 
Table 2: Determinants of Respondents' Output.

\begin{tabular}{|c|c|c|c|c|c|}
\hline Variable & B & $\begin{array}{l}\text { Std. } \\
\text { error }\end{array}$ & $\mathrm{t}$ & sig & $\mathrm{t} \quad \& \quad \mathrm{sig}$ \\
\hline Constant & 7.648 & 2.990 & 2.558 & 0.063 & $-3.002, .065$ \\
\hline Farming experience $\left(\mathrm{X}_{1}\right)$ & -0.675 & 0.225 & -3.002 & 0.065 & \\
\hline Years of education $\left(\mathrm{X}_{2}\right)$ & 1.236 & 0.325 & 3.803 & 0.019 & $3.803,0.019$ \\
\hline Family size $\left(\mathrm{X}_{3}\right)$ & -0.079 & 0.144 & -0.547 & 0.013 & $-0.547, .013$ \\
\hline Amount of fertilizer applied $\left(\mathrm{X}_{4}\right)$ & 0.189 & 0.255 & 0.741 & 0.500 & $0.741, .500$ \\
\hline $\begin{array}{l}\text { Improved cassava stem cuttings } \\
\left(\mathrm{X}_{5}\right)\end{array}$ & 0.492 & 0.187 & 2.633 & 0.058 & $2.633, .058$ \\
\hline $\begin{array}{l}\text { Agrochemical and planting } \\
\text { materials }\left(\mathrm{X}_{6}\right)\end{array}$ & 0.110 & 0.206 & 0.535 & 0.621 & $0.535, .621$ \\
\hline Farm size $\left(X_{7}\right)$ & 0.523 & 0.461 & 1.134 & 0.320 & $1.134, .320$ \\
\hline Amount of labour used $\left(\mathrm{X}_{8}\right)$ & -0.366 & 0.612 & -0.598 & 0.582 & -0.598 \\
\hline Access to Credit (dummy) $\left(\mathrm{X}_{9}\right)$ & -0.681 & 0.209 & -3.258 & 0.031 & $-3.258, .031$ \\
\hline Extension(dummy) $\left(\mathrm{X}_{10}\right)$ & 0.030 & 0.145 & 0.207 & 0.846 & $0.207, .8$ \\
\hline$=0.930$ & & & & & \\
\hline F- Ratio & & & & & \\
\hline
\end{tabular}

Source: Field Survey, 2010

As shown on Table 2, factors that significantly contributed to respondent's output (determinants) were farming experience $\left(X_{1}\right)$, years of education $\left(X_{2}\right)$, family size $\left(X_{3}\right)$, use of improved cassava stem cuttings $\left(X_{5}\right)$, and access to credit $\left(\mathrm{X}_{9}\right)$. Together, the variables included in the model explained $93.0 \%$ of the variation in the cassava output of respondents. These results have a number of implications:

The coefficient of farming experience $\left(X_{1}\right)$ was negative and significant at $10 \%$ level implying its negative contribution to output of non-ADP women farmers. The implication farming experience will tend to reduce output. This could be because as women farmers they grow older, they become more fatigued (due to the heavy burdens they bear), more conservative, and less efficient. This is contrary to Inoni (2008) who found that the age of farmers play a significant role in the income they generate in a year. As the farmer gets older and more experienced the more resources such as labour and land he posses to generate more income. Since increasing age (proxied by farming experience) seems to be a constraint to increased productivity among respondents in this study, a deliberate policy to lessen the women's burdens, and encourage younger women to participate in cassava production through proper information dissemination will go a long way to improve productivity.

The coefficient of years of education $\left(\mathrm{X}_{2}\right)$ was positive and significant at $5 \%$ implying the significant contribution of the variable to output. This implies that increase in years of education will tend to increase output. This is in conformity with Onyeweaku et al (2004) who stated that education increases farmers' productivity. The implied policy is to step up efforts towards women education in the study area for increased productivity.

The coefficient of family size $\left(\mathrm{X}_{3}\right)$ was negative and significant implying that family size had a negative significant contribution to output. This implies that an increase in family size will tend to reduce output and productivity. This is contrary to Inoni (2008) who posited that household (or family) size can contribute positively to output through the supply of labour for farming. The possible explanation could be that money and other resources which could be used to expand the farm and produce more are been used meet the needs of the large family. It could also mean that the families are made up a high proportion of young children and aged people who consume family resources without contributing to family output. Proper education on optimal family size and labour use on the farm could be a way out of the problem.

The coefficient of use of improved cassava stem cuttings $\left(\mathrm{X}_{5}\right)$ was positive and significant at $10 \%$ implying the positive significant contribution of the use of improved cassava to output. This conforms with a priori expectation and agrees with Odii (2003) that use of improved technologies such as improved cassava varieties has positive effect on output and productivity. This has a number of policy implications. The use of improved cassava stem cuttings had a positive significant impact on output but these technologies are however expensive for the poor women farmers. This calls for the provision of more improved cassava technology packages and credit for women farmers to access them. This must be accompanied by the relevant extension information on them.

The coefficient for access to credit $\left(\mathrm{X}_{9}\right)$ was negative and significant at $5 \%$ level implying the significant negative contribution of access to credit to output. This is contrary to a priori expectation of a positive relationship. The result is also contrary to Yusuf and Adenegan (2008) who reported a positive insignificant coefficient of access to credit in their study of technical efficiency among women farmers in Kogi State, Nigeria. This negative result could be due to the well known diversion of production credit non-farm uses common among farmers. The policy implication here is that these women farmers must be provided with adequate credit, and they should be closely monitored to ensure they use the credit for what it was provided 
The study also found that cassava is a high potential and viable crop for food security and poverty reduction in Nigeria. There is adequate potential to produce and supply cassava products to meet both the internal and international demand. This is because of other nations' interest to purchase cassava products (especially chips for starch, ethanol and livestock feed) from Nigeria, the various uses of cassava (industrial, domestic, local and international) all of which have created high demand for the products of cassava. On the supply side, the presidential initiative on cassava production, the various researches and research institutions working on the cassava crop in Nigeria, and the significant difference improved varieties of cassava are making to farmers' yields among other factors indicate the potential for an adequate supply response. This implies that Nigeria could reap meaningful gains (gains that will affect vulnerable groups like women farmers) in poverty reduction by implementing a suitable cassava production policy.

Respondents were asked to identify the production and other problems they have encountered which they consider as limitations to improvement to productivity. Problems identified by respondents were poor pricing of output $(50.6 \%)$, lack of credit $(47.1 \%)$, soil fertility problems (46.0\%), processing problems $(40.2 \%)$, lack of good market infrastructure (34.5\%), labour problems $(31.0 \%)$, and high transport costs, a consequence of the poor road network (27.6).

\section{Conclusion And Recommendations}

This study has considered the factors that reduce or enhance productivity among cassava women farmers in Benue State, Nigeria. Cross sectional data from 87 women farmers drawn from the three Agricultural Zones in the State were used. Descriptive statistics such as mean, frequencies, percentages were used to analyze the data collected. In addition, the ordinary least square regression technique was used to estimate the factors that affect productivity among the respondents. Results showed that the factors which contributed significantly to respondent's output were farming experience $\left(\mathrm{X}_{1}\right)$, years of education $\left(\mathrm{X}_{2}\right)$, family size $\left(\mathrm{X}_{3}\right)$, use of improved cassava stem cuttings $\left(\mathrm{X}_{5}\right)$, and access to credit $\left(\mathrm{X}_{9}\right)$. Together, these variables explained $93.0 \%$ of the variation in the cassava output of respondents. Respondents identified poor pricing of output, lack of credit, soil fertility problems, processing problems, lack of good market infrastructure, labour supply problems, and high transport costs as factors militating against successful cassava production, distribution and utilization in the study area.

Based on these findings the following recommendations are made:

(i) Production resources such as fertilizers, agrochemicals, tractor hiring services, processing facilities, improved seeds and planting materials, agricultural credit should be given to farmers particularly women farmers particularly in the study area. There should be targeted delivery of these inputs to identified women farmer groups to ensure that the materials do not get diverted to non-targets. These production resources should be affordable, provided on time and in enough quantities. The use of these resources as reward for political patronage to the detriment of genuine farmers must be discouraged in the study area.

(ii)Suitable pricing policies for cassava output of farmers should be made as incentives for increased cassava production and improved welfare of cassava producers and their families. Arrangements should be made for farmers (especially women farmers) to readily depose of their output at reasonable prices to encourage more production. Alternatively government and interested investors could buy cassava and process it according to specification. This implies that there is an urgent need to provide a conducive operating environment for investors (foreign or local). This calls for the need to maintain law and order to ensure security of lives and property, and serious sincere efforts at fighting corruption.

(iii)Women farmers should be encouraged to form farmers' cooperatives or join existing ones to pool their resources together and to take advantage of development assistance. Strict supervision to ensure that women farmers do not divert development assistance to non-farm uses should be ensured.

(iv)The government and other stakeholders should rise to the challenge of providing facilities for processing to increase value addition in cassava production to avoid waste, and to serve as an incentive for more production. The processing facilities should be women friendly and must be sited in the rural areas if they are to solve the problems of agricultural processing, rural unemployment, rural-urban migration and others. This will enable Nigeria should exploit the substantial potential to produce and market cassava products both internally and internationally. This could enhance rural incomes and poverty reduction both in the study area and the nation at large.

(v) Rural infrastructure such as roads, hospitals, clean water supply, electricity, schools, communication facilities, market infrastructure and others should be provided to make rural life more comfortable. This would improve farm productivity and check rural-urban migration which is one of the major factors responsible for labour shortages especially in the study area. 


\section{References}

[1]. Afolabi, M. M. (2008), "Women as the pillars of National Economy of Nigeria. A study of Economic Activities of Rural Women in Six Local Government Areas of Ondo State" IAFFE Summer Conference, International Association for Feminist Economics, Torino, Italy, $19^{\text {th }}$ June -21 July 2008

[2]. Alabi, O.O. and Adebayo, C.O (2008), "Net income analysis of onion producers in Zaria local government area of Kaduna state, Nigeria" in proceedings of the $10^{\text {th }}$ annual conference of Nigerian association of agricultural economists held at University of Abuja, Nigeria

[3]. Arene,C.J. and Omoregie, E.M. (1991), "The place of women in agricultural labour force in Nigeria", Beitrage zur tropischen landwirt schaft und. Veterinarmedizin 29, H3, pp277-282

[4]. Ayoola, G. B. (2009), Prodigies of Agricultural Economy and Policy. An inaugural lecture, University of Agriculture, Makurdi. Inaugural Lecture Series No. 9

[5]. BNARDA (1998), The impact of Benue State Agricultural and Rural Development Authority on Agriculture and Rural Development in Benue State, BNARDA, Makurdi, Nigeria.

[6]. CBN (2005), Statistical Bulletin Vol. 16 (CBN), Central Bank of Nigeria, Abuja

[7]. IFAD (1992), The State of World Rural Poverty: A New Development Paradigm, Rome.

[8]. Eboh, E.C., Larsen, B., Oji, K.O., Achike, A.I., Ujah, O.C., Odu, M., Uzochukwu, S.A. and NZE C.C.P.(2006), "Renewable natural resources, sustainable economic growth and poverty reduction in Nigeria" AIAE Research Paper1. Enugu. African Institute of Applied Economics

[9]. Etim, N.A. and Ukoha, O.O (2010), "Analysis of poverty profile of rural households: evidence from South-South Nigeria", Journal of Agriculture Social Science vol 6 no pp48-52 available at: http://www.fspubishers.org, accessed on 04/12/2011.

[10]. IFAD (2001). Nigeria. available at: http://www.ifad.org/media/press,

[11]. Ijere, M. O. (1992), Leading Issues in Rural Development, ACENA Publishers, Enugu.

[12]. Inoni, O.E. (2008), "Impact of rural roads and marketing infrastructure on output and income of farming households in Ughelli south local government area, Delta State", in proceedings of the $10^{\text {th }}$ Annual National Conference of the Nigerian Association of Agricultural Economists held at University of Abuja, $7^{\text {th }}-10^{\text {th }}$ October.

[13]. International Monetary Fund (IMF) (2004), Nigeria poverty reduction strategy paper. National Economic Empowerment and Development Strategy. IMF Country Report No.05/433, Washington D.C.

[14]. National Population Commission (2006), Census figures. Abuja, Nigeria.

[15]. Nsikakabsi, A.E. and O.O. Okoha (2010), "Analysis of poverty profile of rural households: Evidence from South -South Nigeria", Journal of Agriculture and Social Sciences. available at: http//www.fspublishers.org accessed on 12/10/2011.

[16]. Ogbimi, G. E. and Williams, S. (2001), "Gender Sensitivity and Marginalized Groups: Assessment of the Availability of productive Assets to Woman in Agricultural Development", in International Colloquium on Gender, Population and Development in Africa, Abidjan on 16-21 July 2001.

[17]. Okoli, P.I. and Umebali, E.E. (2008), "Revitalizing the Nigerian agriculture to meet the challenges of the $21^{\text {st }}$ century" in proceedings of the $10^{\text {th }}$ annual national conference of the Nigerian Association of Agricultural Economics held at the University of Abuja, Abuja p432-438

[18]. Onyenweaku, C.E., Igwe, K.C and Mbanasor J.A (2004), "Application of stochastic frontier in the measurement technical efficiency in yam production in Nassarawa state, Nigeria", Journal of Sustainable Tropical Agriculture and Agricultural Research, vol,13, pp13.

[19]. United Nations Development Programme (2005), Human Development Report, Oxford University Press, New York. 